\section{Scientific Impact of Central and Eastern European Higher Education Lecturers}

\section{Domagoj Sajter}

Josip Juraj Strossmayer University of Osijek, Faculty of Economics, Croatia sajter@efos.hr

\begin{abstract}
The purpose of this paper is to obtain and analyse data on the higher education lecturers at the 16 largest, state-owned faculties of economics in seven central and eastern European countries (Bosnia and Herzegovina, Croatia, Kosovo, Montenegro, North Macedonia, Serbia, and Slovenia), about their scientific impact and reach. An analysis of their research areas and scientometrics (citations, h-indices) was performed, and aggregate rankings are presented. Data was collected from Google Scholar, Web of Science and Scopus by using proprietary specialized web crawlers ("bots”). The differences among countries and faculties are significant, and institutions should observe good practices from Slovenia, as its faculties are ranked highest. The insights are important for evaluating scientific progress, mobility, and cooperation, rewarding and promotion requirements, accreditations, project and institution funding, and higher education lecturers’ promotion.
\end{abstract}

Keywords: Central and Eastern Europe, economists, Faculty of Economics, scientometrics, h-index, citations

\section{Introduction}

Every higher education lecturer should be devoted to three general areas of his occupation: teaching, science, and public service (AAUP, 2015; Blau, 1996; Boyer, 1997). An academic can be a brilliant pedagogue; great at passing complex knowledge in a simple manner on to students, but less prolific in producing high-quality (i.e.highly-cited) scientific papers (and vice versa). Serving as an expert ("technocrat") within public institution requires a third set of skills - managing people, their conflicted interests, and politics. It is challenging to be superb in each of the three mentioned areas. This paper specifically aims at the scientific reach of a lecturer at a faculty, notwithstanding the obvious need to investigate the others as well.

In this work a new dataset is obtained and analysed: the 16 largest faculties ${ }^{1}$ of economics were selected from state-owned faculties in seven central and eastern European (CEE) countries. The aim is to observe these economists' fields of expertise, scientometrics (citations and h-index from different scientific data providers), and to comparatively analyse them. The data is harvested and published online ${ }^{2}$ with open access. As such, this is the very initial work, hopefully building a foundation for a wider discussion and further research.
ORIGINAL SCIENTIFIC PAPER

RECEIVED: FEBRUARY 2021

REVISED: JUNE 2021

ACCEPTED: AUGUST 2021

DOI: $10.2478 /$ ngoe-2021-0014

UDK: 378:001.891(4-191.2)

JEL: A11, A22, A23

Citation: Sajter, D. (2021). Scientific Impact of Central and Eastern European Higher Education Lecturers. Naše gospodarstvo/Our Economy, 67(3), 17-28. DOI: 10.2478/ngoe-2021-0014

\section{NG OE}

NAŠE GOSPODARSTVO OUR ECONOMY

Vol. 67 No. 32021

pp. 17-28 
To the best of our knowledge, there are no previous studies which comparatively examine the scientific impact of CEE higher education lecturers of economics, and this was the prime motivation for this paper. However, there are many studies which observe impact factors, citations, and similar metrics of economists, as well as designated journals (e.g., Scientometrics, e-ISSN: 1588-2861). Kocher et al. (2006) measured productivity in top economic research by using data envelopment analysis in 21 OECD-countries. Wolszczak-Derlacz and Parteka (2011) sampled 259 public higher education institutions from 7 European countries (Austria, Finland, Germany, Italy, Poland, Switzerland, and the United Kingdom) across the time period of 2001-2005, and evaluated efficiency in publication and graduations. Jurajda et al. (2017) presented a bibliometric comparison of publication performance in 226 scientific disciplines in the Web of Science (WoS) for six post-communist EU member states (Czech Republic, Hungary, Poland, Slovakia, Slovenia, and Croatia). Candan (2020) explored the efficiency and performance of economics research in 15 OECD member countries and evaluated them by using bibliometric elements for the period of 2010-2017, but only Hungary from CEE was included.

Previous researchers did not encompass the countries selected for this study, and this is a gap that this paper aims to fill. We can empirically observe differences among the scientific impact of lecturers at the faculties of economics in the CEE region. Therefore, the research questions can be stated as: are these differences factual and significant, and what is their scope?

After this introduction which included a brief overview of the previous literature, the second chapter delves into methodology and the data obtained (with detailed review of data preparation), while the third presents and discusses results. Finally, the fourth chapter concludes.

\section{Methodology and Data}

After composing the research questions, this study began with the collection of data on the academic (teaching) staff from the official websites of the 16 faculties of economics from seven neighbouring, transition CEE countries (Bosnia and Herzegovina, Croatia, Kosovo, Montenegro, North Macedonia, Serbia, and Slovenia), as presented in Table 1. From each of the larger countries three faculties in their largest cities were selected, ${ }^{3}$ while smaller countries (where larger and smaller countries are differentiated by the criterion of population and area) were sampled with one, from the capital. The chosen CEE countries share a portion of their modern history and have comparable and compatible scientific systems (e.g., identical academic titles, similar structures, etc.), and can easily communicate through some unofficial version of amalgamated Bosnian-Croatian-Serbian language. However, their higher education systems are fragmented, and many lecturers do not have proper tools for collaboration and networking, which is one of the motivations for this research.

The sample was designed by selecting faculties from stateowned, public faculties because they have a particular scientific heritage and background, as opposed to those privately owned. Moreover, state-owned faculties in this region are largely financed with public resources, which weighs them with more accountability for their scientific accomplishments and gives taxpayers the privilege of demanding more information on their performances.

It can be seen that the size of the faculties, as measured by the number of teaching staff (Figure 1), is more or less similar, with the exception of Zagreb which has twice as many lecturers as, e.g., Belgrade and almost 8 times more than the lowest in the sample (Mostar). The sheer size of the Zagreb Faculty will push its aggregate scientometrics upwards; together with the unequal number of lecturers among countries this emphasises the need to maintain focus on measures of central tendency when discussing results.

Figure 1. Total number of teaching staff at selected CEE faculties of economics

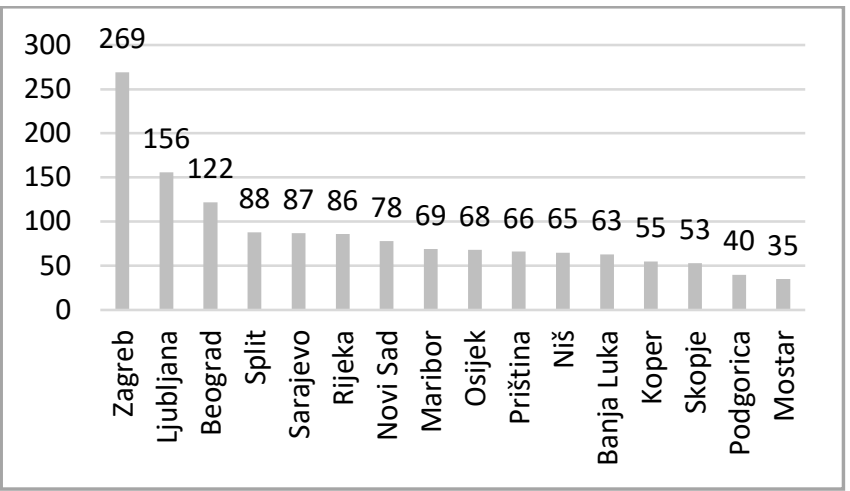

Source: Author’s research

Non-economists teaching at faculties of economics (typically involved in languages and law) were not excluded from the teaching staff mostly because their contribution to the scientific impact of their local community was assumed to be a valuable asset and important benefit to international visibility and recognition of their faculties. This was also done because many academics have complex expertise and it would be impossible to disentangle their interdisciplinarity into clear-cut categories.

\section{Scientometrics providers and data collection process}

After compiling all the data on the lecturers (as in Table 1), for each of the staff members, three data providers were queried: Web of Science (WoS), Scopus, and Google Scholar. These were chosen to obtain better insight into differences between them, because their data collection designs are different, and because they are commonly used and prevalent in the scientific community. Also, in some CEE countries there are formal requirements for lecturers to have a Google Scholar profile and to publish in journals indexed 
by WoS and Scopus (e.g., Croatia). Waltman (2016) provides an in-depth review of the literature on citation impact indicators from Web of Science, Scopus, and Google Scholar. The differences between the databases are extensively explicated in the next section.

By using specialized web crawlers ("bots") developed particularly for this research, during May and June 2020 from

Table 1. Faculties in the sample and their teaching staff a) some colleagues have vague, imprecise or even incorrect affiliations, and some have multiple affiliations,

b) data providers often rely on authors to comb through articles and to (dis)associate themselves from papers, and if authors have not done it recently this gives room for improperly conjoined authorships (with some authors having greater scientometrics

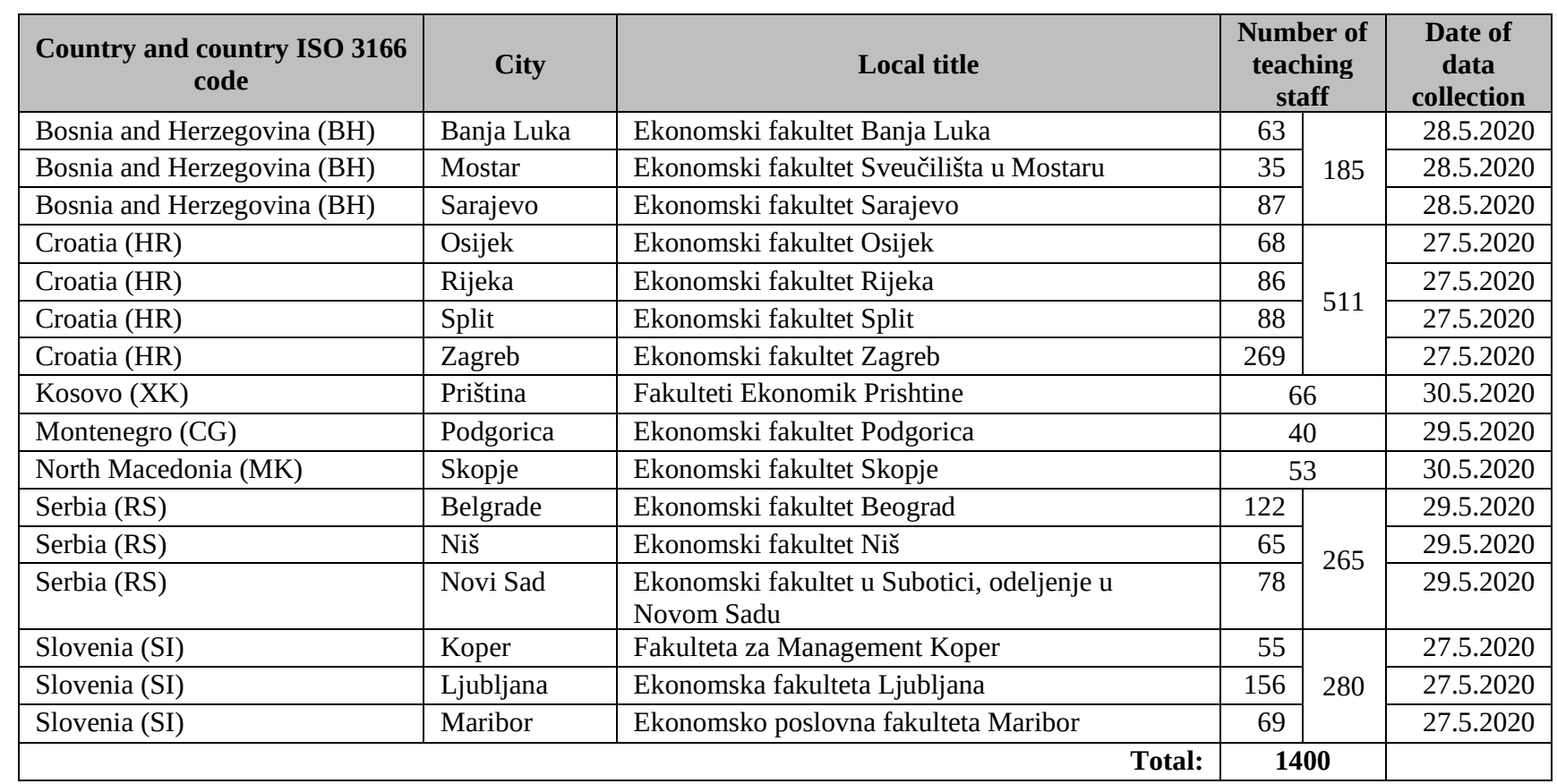

Source: Author's research

these providers a selection of ten scientometrics was extracted for each staff member:

- from WoS: 1) total number of citations and 2) hindex, ${ }^{4}$

- from Scopus: 3) total number of citations and 4) hindex,

- from Google Scholar: 5) all-time total of citations, 6) all-time h-index, 7) all-time i10 index, 8) citations since 2015, 9) h-index since 2015, and 10) i10 index since 2015.

To maintain conciseness and comparability analysis was done over six metrics: all-time citations and h-index, from WoS, Scopus, and Scholar.

The process of data harvesting was cumbersome and had to be repeated several times with subsequent refinements and special-cases filtering (which was performed manually, by comparing and contrasting observed data from three databases, as it was infeasible to perform it by employing artificial intelligence), due to the following challenges and limitations: then they should have, while others have lower);

c) if there were no results for particular name and surname some data providers went for the "next best thing" - they gave results for similar looking and/or sounding names or surnames, which deceived bots into collecting data for a different person instead of what was asked for (e.g., when searching for Aleksandar X, Google Scholar displays Aleksandra $\mathrm{X}$, etc.);

d) many colleagues have changed their surname which led bots to no results when looking for scientometrics under current last name,

e) some colleagues have the same name and surname as their counterparts from other scientific fields, which misled bots into collecting data from noneconomists;

f) many colleagues have two last names, and some scientometric providers differentiate when having a dash between them (Surname1-Surname2 regarded differently as Surname1 Surname2);

g) the treatment of letter " $Đ$ " - some providers transform it into D which renders searches with "Đ” within name or surname without any results;

h) etc. 
If no profile was found at WoS, Scopus, or Google Scholar after repeated searches as stated above, it was assumed that the scientometrics for the given person are equal to zero. This does not imply that this person has no scientific merit or impact, only that (given challenges and limitations of this research) chosen scientific online data providers did not (yet) encompass them.

Detailed proofing of every single of the 4,200 queries $(1,400$ lecturers from three data providers) and 14,000 metrics was both unfeasible and would defeat the purpose of this paper, and because of the above reasons it should be noted that some errors have likely remained in the database. Nevertheless, it can be stated that these are in the absolute minority, and that the general conclusions of this research can stand regardless of possible errors.

\section{Scientometric data}

The well-known and widely used h-index was developed by Hirsch (2005). It reflects the productivity of authors based on their publication and citation records.

At WoS the h-index is based on the WoS Core Collection citations of the publications shown on the author record. WoS Core Collection comprises of six sub-databases (Web of Science, 2020a). WoS declares (Web of Science, 2020b) that the h-index reflects not just the number of papers or the number of citations, but (since it is not influenced by a single highly-cited paper) that it provides some indication of the number of well-cited papers. However, the h-index is dependent on the subject area considered, as well as on the time since publication of important papers.

Scopus (a brand of Elsevier) covers some 23,500 peerreviewed journals, including 5,500 full open access journals, 300 trade publications, 850 book series, 9.8 million conference papers from 120,000 events, 210,000 books, and over 77.8 million records (Scopus, 2020a). It declares that their h-index is based on the highest number of papers included that have had at least the same number of citations, and also advises that it should only be used in a mix of quantitative and qualitative metrics (Scopus, 2020b).

Google Scholar does not declare specifically which sources it includes, only that it currently covers articles published between 2014 and 2018, with the exclusion of patents, books, and dissertations, publications with fewer than 100 articles published between 2014 and 2018, and publications that received no citations to articles published between 2014 and 2018. It claims to cover a "substantial fraction of scholarly articles published in the last five years. However, [we] don't currently cover a large number of articles from smaller publications” (Google LLC, 2020). Google Scholar is free access and covers a wider area of publications, not only scholarly reviewed papers, but also websites, blogs, newspapers, etc. As such it can be viewed as a tool to gain some insight into wider public - not only scientific - impact. It also publishes the i10-index, the number of publications with at least 10 citations.
The differences between the providers makes the data obtained from them complementary, but not interchangeable; hence we employ all three in order to gain a wider and fuller perspective.

Finally, after testing for normality ANOVA/Kruskal-Wallis will show whether the differences between average citations and h-indices among faculties (cities) and among countries are significant.

\section{Results and Discussion}

Many lecturers do not have profiles at WoS, Scopus nor Google Scholar, and it is also clear that countries rely differently on scientific data providers (Figure 2). More than $70 \%$ of lecturers in Slovenia do not have a Google Scholar profile, as opposed to only $18 \%$ in Croatia where that is mandatory for academic advancement. Every researcher is free and can choose not to have a Google Scholar profile, but since Google is the primary global data provider this decision has consequences on the visibility, impact, and influence of that researcher. Within this study it should also be acknowledged that Google Scholar is valuable since it enables authors themselves to declare their own narrow research interests (a feature not available elsewhere, as other databases merely categorize everyone within economics), which then brings substantial additional value to the data obtained by other sources.

On the other hand, Slovenia has the lowest aggregates of lecturers that do not have WoS or Scopus profile. At the overall average, approximately half of the lecturers do not have any profile whatsoever at WoS, Scopus, or Google Scholar. It should be noted that some of the lecturers' scientific impact is here "invisible" when their papers are published in their native language (non-English).

When comparing scientometrics harvested from data providers, it is important to note that Scholar has different sources and that it diverges somewhat from both Scopus and WoS. Figure 3 (logarithmically scaled) presents each author as a single datapoint with total citations as coordinates. On the other hand, WoS and Scopus share much more resemblance and they could nearly be regarded as alternatives or substitutes for each other (Figure 4, again with log-scales).

The descriptive statistics of the number of citations and the h-index, grouped by countries, are given in Table 2 and Table 3 , respectively. The trimmed mean is calculated by removing $1 \%$ of values from both ends of the data set, thereby retaining $98 \%$ of the mid-data, and is useful to compare central tendency without outliers. 
Figure 2. Percentage of staff that do not have any data from data providers, by country

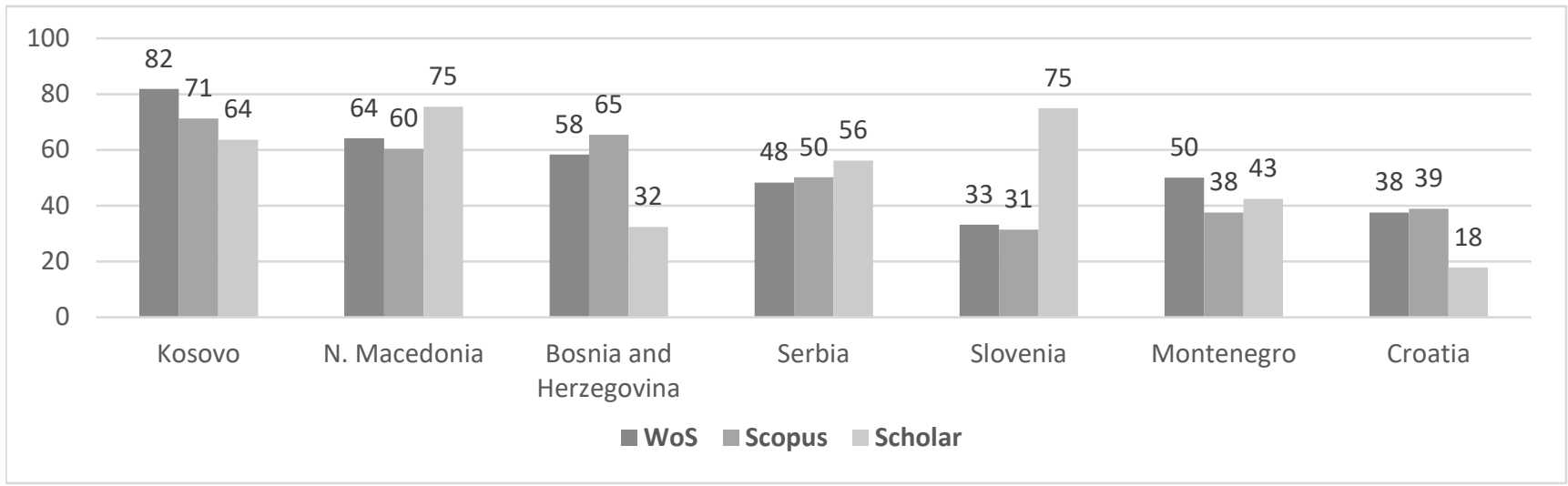

Source: Author's research

Table 2. Descriptive statistics of citations, grouped by countries, sorted by mean

\begin{tabular}{|c|c|c|c|c|c|c|c|c|c|}
\hline Data provider & Country & $\begin{array}{c}\text { Valid } \\
\mathbf{N}\end{array}$ & Mean & $\begin{array}{c}\text { Trimmed } \\
\text { mean }\end{array}$ & Sum & Min. & Max. & $\begin{array}{l}\text { Std. } \\
\text { Dev. }\end{array}$ & $\begin{array}{l}\text { Coef. } \\
\text { Var. }\end{array}$ \\
\hline \multirow{7}{*}{ Google Scholar } & Slovenia & 280 & 309 & 241 & 86430 & 0 & 10579 & 1013 & 328 \\
\hline & Croatia & 511 & 197 & 178 & 100708 & 0 & 2836 & 355 & 180 \\
\hline & Serbia & 265 & 71 & 63 & 18731 & 0 & 999 & 139 & 197 \\
\hline & Bosnia \& H. & 185 & 64 & 48 & 11865 & 0 & 2192 & 198 & 308 \\
\hline & Montenegro & 40 & 31 & 31 & 1249 & 0 & 173 & 40 & 129 \\
\hline & N. Macedonia & 53 & 28 & 21 & 1486 & 0 & 419 & 69 & 247 \\
\hline & Kosovo & 66 & 19 & 17 & 1256 & 0 & 190 & 40 & 208 \\
\hline \multirow{7}{*}{ Scopus } & Slovenia & 280 & 135 & 112 & 37740 & 0 & 2968 & 320 & 237 \\
\hline & Croatia & 511 & 25 & 19 & 12936 & 0 & 923 & 78 & 309 \\
\hline & Serbia & 265 & 17 & 14 & 4448 & 0 & 409 & 43 & 257 \\
\hline & Montenegro & 40 & 12 & 12 & 468 & 0 & 145 & 26 & 226 \\
\hline & Bosnia \& H. & 185 & 14 & 9 & 2521 & 0 & 574 & 53 & 388 \\
\hline & N. Macedonia & 53 & 8 & 5 & 445 & 0 & 187 & 27 & 317 \\
\hline & Kosovo & 66 & 7 & 3 & 451 & 0 & 280 & 35 & 513 \\
\hline \multirow{7}{*}{ WoS } & Slovenia & 280 & 103 & 86 & 28846 & 0 & 2286 & 247 & 240 \\
\hline & Croatia & 511 & 25 & 20 & 13000 & 0 & 1356 & 85 & 333 \\
\hline & Serbia & 265 & 21 & 18 & 5435 & 0 & 312 & 49 & 240 \\
\hline & Montenegro & 40 & 10 & 10 & 409 & 0 & 112 & 22 & 217 \\
\hline & Bosnia \& H. & 185 & 14 & 10 & 2573 & 0 & 560 & 51 & 368 \\
\hline & N. Macedonia & 53 & 4 & 3 & 230 & 0 & 67 & 11 & 256 \\
\hline & Kosovo & 66 & 6 & 2 & 379 & 0 & 271 & 34 & 588 \\
\hline
\end{tabular}

Source: Author's calculation

Figure 3. Citations from Scholar vs. Scopus and WoS

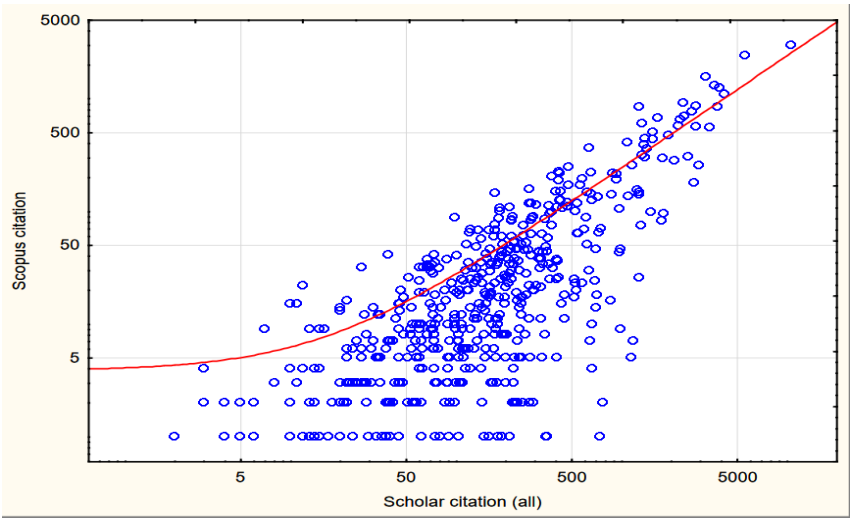

Source: Author's research

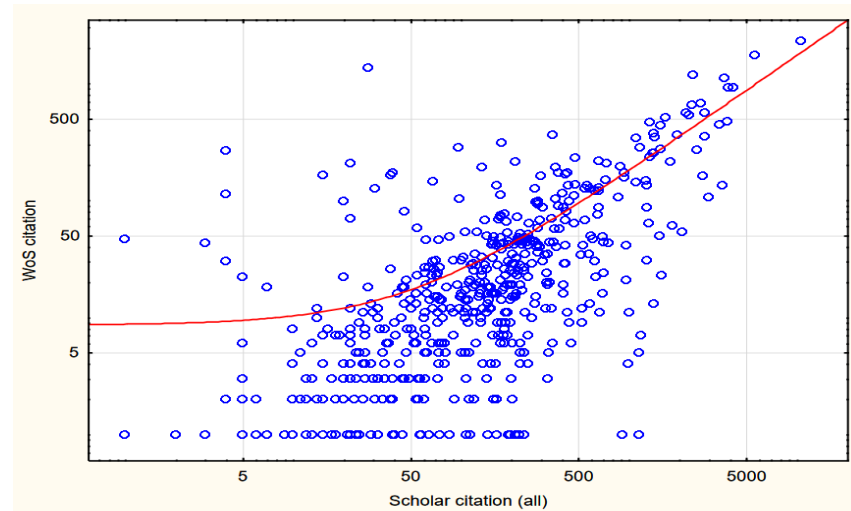

Source: Author's research 
Figure 4. Citations from Scopus vs WoS

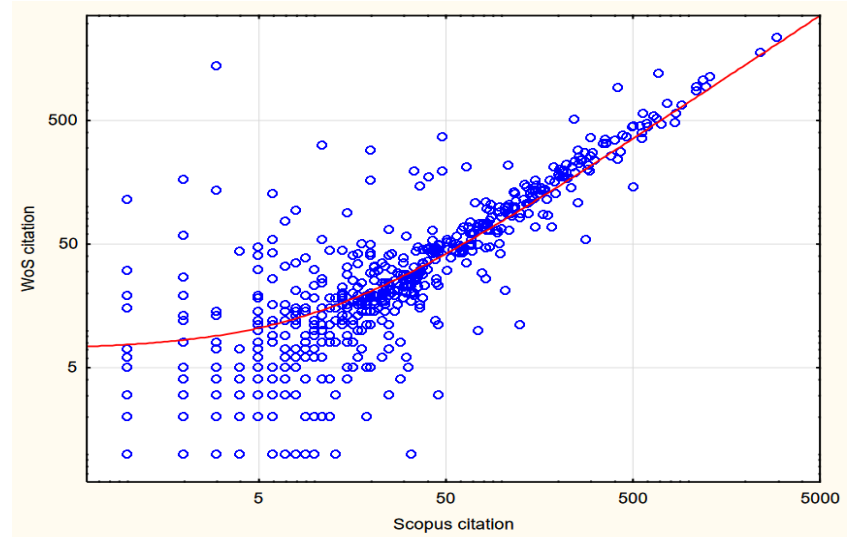

Source: Author's research

Since WoS and Scopus share resemblance as visualized in Figure 4, rankings of countries by average citations from WoS and Scopus are identical. However, there is a large gap between Slovenia and other CEE countries in the sample, with Slovenian lecturers having approx. four times more citations at WoS and Scopus than the second best (Croatia), while the differences between the third and the rest are not as stark (Figure 5). Figure 5 (as well as Graph 6) present the relative numbers (averages).

Figure 5. Arithmetic means of citations, by country

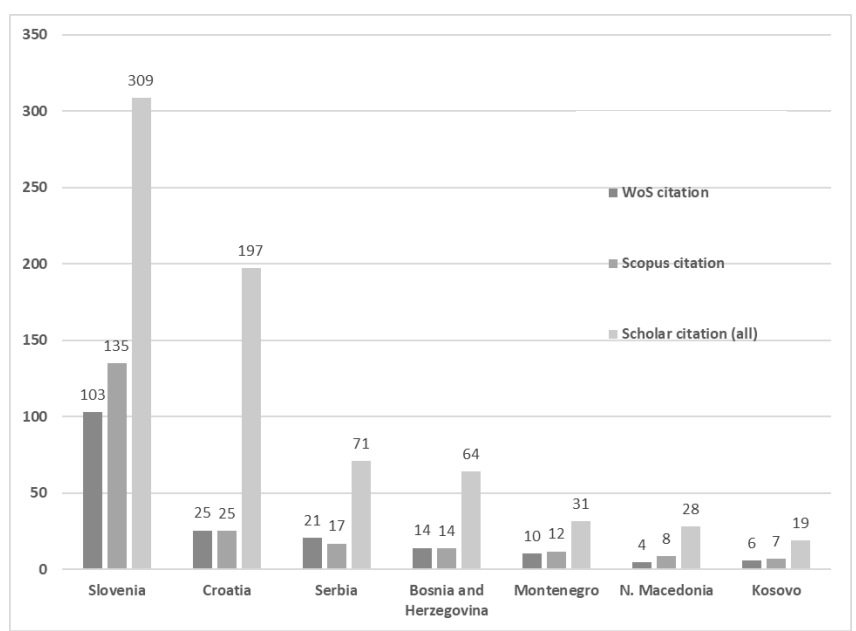

Source: Author's calculation

When analysing countries according to their h-indices similar patterns emerge: Slovenia leads the way at WoS and Scopus, but at Google Scholar Croatian lecturers present much more impact than their CEE counterparts. However, it should be kept in mind that approximately $75 \%$ of Slovenian lecturers do not have Scholar profile. The obligation in Croatia to have Google Scholar profile when commencing the academic advancement procedure most likely is an important factor here.

Figure 6 exhibits that when focusing on average h-index, Croatian lecturers have much more impact through Google Scholar than through other providers.
Figure 6. Arithmetic mean of h-index, by country

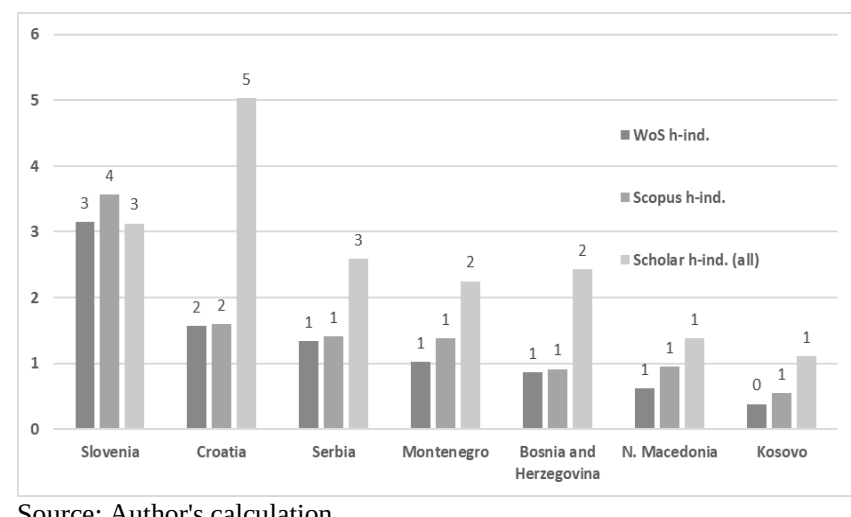

Source: Author's calculation

Economic inequalities could also explain intra-national variances, which come into play when the focus shifts from countries to cities. The descriptive statistics of the number of citations and the h-index, grouped by cities, are given in Table 4 and Table 5, respectively.

As expected, the highest positions are held by faculties in Slovenia, followed by the institutions from the largest cities (capitals). However, there are some surprising results, such as the relatively low rank of Belgrade.

Economic inequalities could also explain intra-national variances, which come into play when the focus shifts from countries to cities. The descriptive statistics of the number of citations and the h-index, grouped by cities, are given in Table 4 and Table 5, respectively.

As expected, the highest positions are held by faculties in Slovenia, followed by the institutions from the largest cities (capitals). However, $t$ here are some surprising results, such as the relatively low rank of Belgrade.

When we turn to the h-index grouped by cities, we see (Table 5) that it mostly follows the statistics of citations. The exceptions are Croatian faculties at Google Scholar which are ranked as the top four. 
Table 3. Descriptive statistics of h-index, grouped by countries, sorted by mean

\begin{tabular}{|c|c|c|c|c|c|c|c|c|c|}
\hline Data provider & Country & Valid N & Mean & $\begin{array}{c}\text { Trimmed } \\
\text { mean }\end{array}$ & Sum & Min. & Max. & $\begin{array}{l}\text { Std. } \\
\text { Dev. }\end{array}$ & $\begin{array}{l}\text { Coef. } \\
\text { Var. }\end{array}$ \\
\hline \multirow{7}{*}{ Google Scholar } & Croatia & 511 & 5.03 & 4.90 & 2572 & 0 & 26 & 4 & 88 \\
\hline & Slovenia & 280 & 3.13 & 2.85 & 876 & 0 & 33 & 7 & 218 \\
\hline & Serbia & 265 & 2.59 & 2.49 & 687 & 0 & 15 & 4 & 138 \\
\hline & Bosnia \& H. & 185 & 2.43 & 2.31 & 450 & 0 & 19 & 3 & 120 \\
\hline & Montenegro & 40 & 2.25 & 2.25 & 90 & 0 & 8 & 2 & 104 \\
\hline & N. Macedonia & 53 & 1.38 & 1.22 & 73 & 0 & 11 & 3 & 193 \\
\hline & Kosovo & 66 & 1.11 & 0.98 & 73 & 0 & 10 & 2 & 166 \\
\hline \multirow{7}{*}{ Scopus } & Slovenia & 280 & 3.56 & 3.43 & 997 & 0 & 22 & 4 & 114 \\
\hline & Croatia & 511 & 1.59 & 1.50 & 814 & 0 & 16 & 2 & 129 \\
\hline & Montenegro & 40 & 1.40 & 1.33 & 55 & 0 & 6 & 2 & 117 \\
\hline & Serbia & 265 & 1.38 & 1.38 & 372 & 0 & 11 & 2 & 129 \\
\hline & Bosnia \& H. & 185 & 0.94 & 0.80 & 169 & 0 & 10 & 2 & 185 \\
\hline & N. Macedonia & 53 & 0.91 & 0.83 & 50 & 0 & 9 & 2 & 167 \\
\hline & Kosovo & 66 & 0.55 & 0.42 & 36 & 0 & 9 & 1 & 235 \\
\hline \multirow{7}{*}{ WoS } & Slovenia & 280 & 3.15 & 3.03 & 883 & 0 & 20 & 4 & 119 \\
\hline & Croatia & 511 & 1.57 & 1.49 & 798 & 0 & 15 & 2 & 127 \\
\hline & Serbia & 265 & 1.33 & 1.26 & 353 & 0 & 10 & 2 & 137 \\
\hline & Montenegro & 40 & 1.03 & 1.03 & 41 & 0 & 6 & 1 & 141 \\
\hline & Bosnia \& H. & 185 & 0.86 & 0.80 & 160 & 0 & 9 & 1 & 172 \\
\hline & N. Macedonia & 53 & 0.62 & 0.55 & 33 & 0 & 5 & 1 & 173 \\
\hline & Kosovo & 66 & 0.38 & 0.25 & 25 & 0 & 9 & 1 & 323 \\
\hline
\end{tabular}

Source: Author's calculation

Figure 7. Arithmetic mean of citations, by city

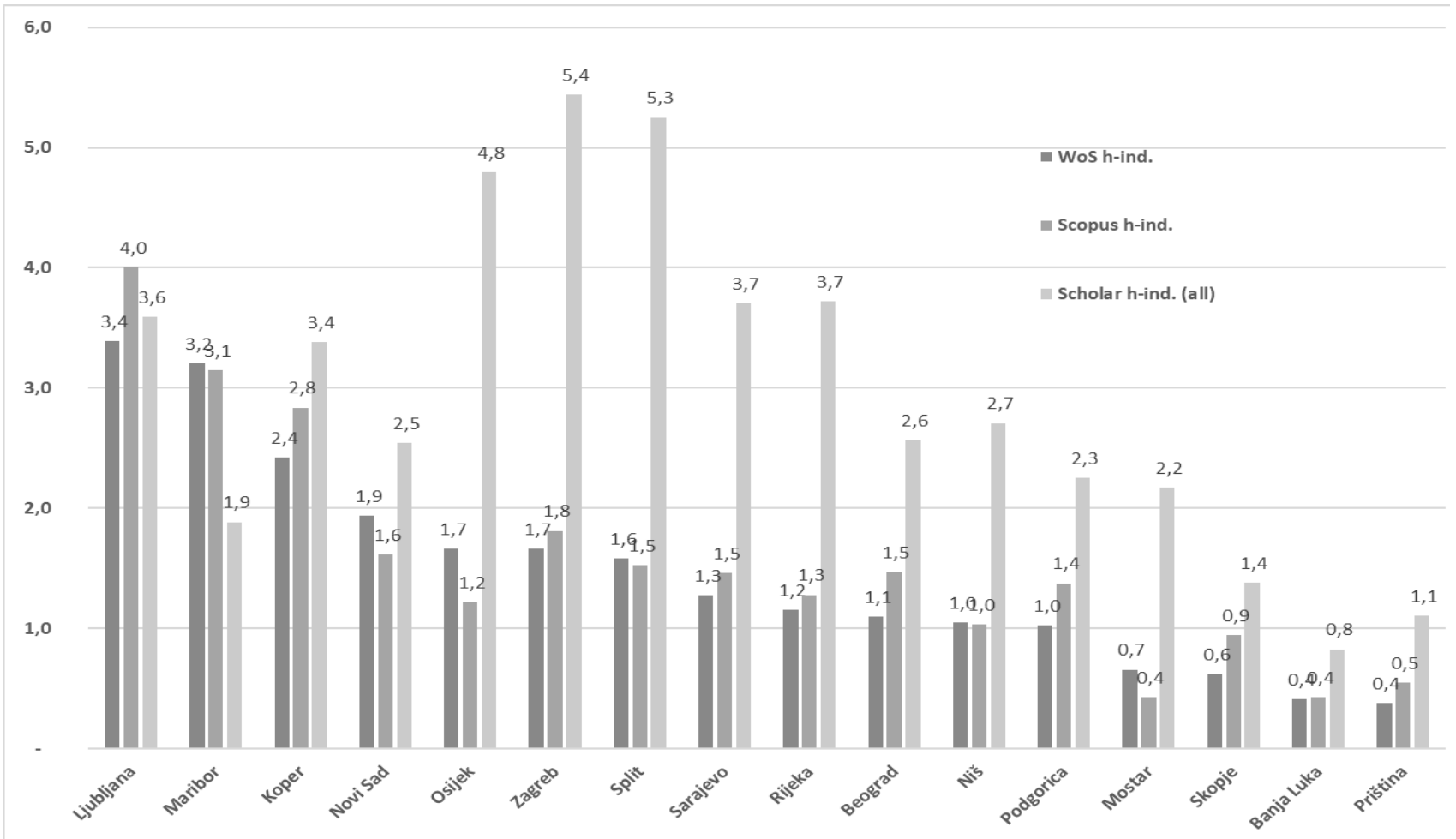

Source: Author's calculation 
Table 4. Descriptive statistics of citations, grouped by cities, sorted by mean

\begin{tabular}{|c|c|c|c|c|c|c|c|c|c|}
\hline $\begin{array}{l}\text { Data } \\
\text { provider }\end{array}$ & City & Valid N & Mean & $\begin{array}{c}\text { Trimmed } \\
\text { mean }\end{array}$ & Sum & Min. & Max. & $\begin{array}{l}\text { Std. } \\
\text { Dev. }\end{array}$ & $\begin{array}{l}\text { Coef. } \\
\text { Var. }\end{array}$ \\
\hline \multirow{16}{*}{$\begin{array}{l}\text { Google } \\
\text { Scholar }\end{array}$} & Ljubljana & 156 & 409 & 313 & 63776 & 0 & 10579 & 1258 & 308 \\
\hline & Zagreb & 269 & 244 & 219 & 65560 & 0 & 2836 & 443 & 182 \\
\hline & Koper & 55 & 226 & 170 & 12455 & 0 & 3440 & 634 & 280 \\
\hline & Split & 88 & 184 & 177 & 16166 & 0 & 975 & 214 & 116 \\
\hline & Osijek & 68 & 151 & 136 & 10250 & 0 & 1255 & 238 & 158 \\
\hline & Maribor & 69 & 148 & 114 & 10199 & 0 & 2529 & 479 & 324 \\
\hline & Sarajevo & 87 & 107 & 84 & 9333 & 0 & 2192 & 261 & 243 \\
\hline & Rijeka & 86 & 102 & 92 & 8732 & 0 & 1002 & 176 & 173 \\
\hline & Belgrade & 122 & 83 & 76 & 10088 & 0 & 999 & 170 & 206 \\
\hline & Niš & 65 & 66 & 57 & 4302 & 0 & 713 & 122 & 185 \\
\hline & Novi Sad & 78 & 56 & 51 & 4341 & 0 & 443 & 88 & 158 \\
\hline & Mostar & 35 & 53 & 53 & 1843 & 0 & 1004 & 169 & 320 \\
\hline & Podgorica & 40 & 31 & 31 & 1249 & 0 & 173 & 40 & 129 \\
\hline & Skopje & 53 & 28 & 21 & 1486 & 0 & 419 & 69 & 247 \\
\hline & Priština & 66 & 19 & 17 & 1256 & 0 & 190 & 40 & 208 \\
\hline & Banja Luka & 63 & 11 & 9 & 689 & 0 & 115 & 27 & 250 \\
\hline \multirow{16}{*}{ Scopus } & Ljubljana & 156 & 176 & 145 & 27498 & 0 & 2968 & 399 & 226 \\
\hline & Koper & 55 & 93 & 73 & 5095 & 0 & 1206 & 212 & 229 \\
\hline & Maribor & 69 & 75 & 68 & 5147 & 0 & 569 & 110 & 147 \\
\hline & Zagreb & 269 & 30 & 23 & 8160 & 0 & 923 & 90 & 295 \\
\hline & Sarajevo & 87 & 24 & 18 & 2106 & 0 & 574 & 71 & 295 \\
\hline & Rijeka & 86 & 22 & 14 & 1895 & 0 & 719 & 89 & 403 \\
\hline & Belgrade & 122 & 21 & 18 & 2515 & 0 & 409 & 54 & 264 \\
\hline & Split & 88 & 19 & 18 & 1703 & 0 & 195 & 37 & 190 \\
\hline & Osijek & 68 & 17 & 14 & 1178 & 0 & 256 & 50 & 287 \\
\hline & Novi Sad & 78 & 15 & 14 & 1189 & 0 & 108 & 25 & 167 \\
\hline & Podgorica & 40 & 12 & 12 & 468 & 0 & 145 & 26 & 226 \\
\hline & Niš & 65 & 11 & 8 & 744 & 0 & 248 & 35 & 308 \\
\hline & Skopje & 53 & 8 & 5 & 445 & 0 & 187 & 27 & 317 \\
\hline & Priština & 66 & 7 & 3 & 451 & 0 & 280 & 35 & 513 \\
\hline & Banja Luka & 63 & 5 & 2 & 344 & 0 & 236 & 30 & 550 \\
\hline & Mostar & 35 & 2 & 2 & 71 & 0 & 31 & 6 & 299 \\
\hline \multirow{16}{*}{ WoS } & Ljubljana & 156 & 130 & 107 & 20272 & 0 & 2286 & 304 & 234 \\
\hline & Maribor & 69 & 70 & 65 & 4853 & 0 & 504 & 104 & 147 \\
\hline & Koper & 55 & 68 & 51 & 3721 & 0 & 1037 & 177 & 261 \\
\hline & Rijeka & 86 & 29 & 14 & 2525 & 0 & 1356 & 154 & 525 \\
\hline & Novi Sad & 78 & 27 & 23 & 2088 & 0 & 309 & 54 & 201 \\
\hline & Zagreb & 269 & 26 & 20 & 6866 & 0 & 659 & 69 & 270 \\
\hline & Osijek & 68 & 24 & 20 & 1621 & 0 & 282 & 51 & 215 \\
\hline & Sarajevo & 87 & 23 & 17 & 2043 & 0 & 560 & 71 & 302 \\
\hline & Split & 88 & 23 & 19 & 1988 & 0 & 360 & 47 & 207 \\
\hline & Niš & 65 & 18 & 14 & 1168 & 0 & 312 & 51 & 284 \\
\hline & Belgrade & 122 & 18 & 16 & 2179 & 0 & 250 & 45 & 253 \\
\hline & Podgorica & 40 & 10 & 10 & 409 & 0 & 112 & 22 & 217 \\
\hline & Priština & 66 & 6 & 2 & 379 & 0 & 271 & 34 & 588 \\
\hline & Banja Luka & 63 & 6 & 4 & 359 & 0 & 140 & 21 & 376 \\
\hline & Mostar & 35 & 5 & 5 & 171 & 0 & 47 & 11 & 217 \\
\hline & Skopje & 53 & 4 & 3 & 230 & 0 & 67 & 11 & 256 \\
\hline
\end{tabular}

Source: Author's calculation 
Table 5. Descriptive statistics of h-index, grouped by cities, sorted by mean

\begin{tabular}{|c|c|c|c|c|c|c|c|c|c|}
\hline $\begin{array}{l}\text { Data } \\
\text { provider }\end{array}$ & City & Valid N & Mean & $\begin{array}{c}\text { Trimmed } \\
\text { mean }\end{array}$ & Sum & Min. & Max. & $\begin{array}{l}\text { Std. } \\
\text { Dev. }\end{array}$ & $\begin{array}{l}\text { Coef. } \\
\text { Var. }\end{array}$ \\
\hline \multirow{16}{*}{$\begin{array}{l}\text { Google } \\
\text { Scholar }\end{array}$} & Zagreb & 269 & 5.44 & 5.29 & 1464 & 0 & 26 & 5 & 92 \\
\hline & Split & 88 & 5.25 & 5.19 & 462 & 0 & 16 & 4 & 74 \\
\hline & Osijek & 68 & 4.79 & 4.68 & 326 & 0 & 17 & 4 & 80 \\
\hline & Rijeka & 86 & 3.72 & 3.62 & 320 & 0 & 16 & 3 & 88 \\
\hline & Sarajevo & 87 & 3.70 & 3.56 & 322 & 0 & 19 & 3 & 89 \\
\hline & Ljubljana & 156 & 3.59 & 3.28 & 560 & 0 & 31 & 7 & 208 \\
\hline & Koper & 55 & 3.38 & 2.89 & 186 & 0 & 33 & 6 & 190 \\
\hline & Niš & 65 & 2.71 & 2.59 & 176 & 0 & 13 & 4 & 131 \\
\hline & Belgrade & 122 & 2.57 & 2.48 & 313 & 0 & 15 & 4 & 151 \\
\hline & Novi Sad & 78 & 2.54 & 2.46 & 198 & 0 & 11 & 3 & 122 \\
\hline & Podgorica & 40 & 2.25 & 2.25 & 90 & 0 & 8 & 2 & 104 \\
\hline & Mostar & 35 & 2.17 & 2.17 & 76 & 0 & 13 & 2 & 110 \\
\hline & Maribor & 69 & 1.88 & 1.61 & 130 & 0 & 22 & 5 & 281 \\
\hline & Skopje & 53 & 1.38 & 1.22 & 73 & 0 & 11 & 3 & 193 \\
\hline & Priština & 66 & 1.11 & 0.98 & 73 & 0 & 10 & 2 & 166 \\
\hline & Banja Luka & 63 & 0.83 & 0.75 & 52 & 0 & 6 & 1 & 180 \\
\hline \multirow{16}{*}{ Scopus } & Ljubljana & 156 & 4.00 & 3.84 & 624 & 0 & 22 & 4 & 112 \\
\hline & Maribor & 69 & 3.14 & 3.03 & 217 & 0 & 14 & 3 & 103 \\
\hline & Koper & 55 & 2.84 & 2,62 & 156 & 0 & 17 & 4 & 126 \\
\hline & Zagreb & 269 & 1.81 & 1.70 & 487 & 0 & 16 & 2 & 125 \\
\hline & Novi Sad & 78 & 1.62 & 1.57 & 126 & 0 & 7 & 2 & 108 \\
\hline & Split & 88 & 1.52 & 1.49 & 134 & 0 & 6 & 1 & 93 \\
\hline & Belgrade & 122 & 1.47 & 1.40 & 179 & 0 & 11 & 2 & 137 \\
\hline & Sarajevo & 87 & 1.46 & 1.38 & 127 & 0 & 10 & 2 & 142 \\
\hline & Podgorica & 40 & 1.38 & 1.38 & 55 & 0 & 6 & 2 & 117 \\
\hline & Rijeka & 86 & 1.28 & 1.15 & 110 & 0 & 13 & 2 & 156 \\
\hline & Osijek & 68 & 1.22 & 1.14 & 83 & 0 & 8 & 2 & 152 \\
\hline & Niš & 65 & 1.03 & 0.97 & 67 & 0 & 6 & 1 & 134 \\
\hline & Skopje & 53 & 0.94 & 0.80 & 50 & 0 & 9 & 2 & 167 \\
\hline & Priština & 66 & 0.55 & 0.42 & 36 & 0 & 9 & 1 & 235 \\
\hline & Banja Luka & 63 & 0.43 & 0.33 & 27 & 0 & 7 & 1 & 277 \\
\hline & Mostar & 35 & 0.43 & 0.43 & 15 & 0 & 3 & 1 & 172 \\
\hline \multirow{16}{*}{ WoS } & Ljubljana & 156 & 3.39 & 3.24 & 529 & 0 & 20 & 4 & 122 \\
\hline & Maribor & 69 & 3.20 & 3.10 & 221 & 0 & 13 & 3 & 101 \\
\hline & Koper & 55 & 2.42 & 2.23 & 133 & 0 & 15 & 3 & 131 \\
\hline & Novi Sad & 78 & 1.94 & 1.88 & 151 & 0 & 8 & 2 & 91 \\
\hline & Osijek & 68 & 1.66 & 1.58 & 113 & 0 & 9 & 2 & 103 \\
\hline & Zagreb & 269 & 1.66 & 1.56 & 447 & 0 & 15 & 2 & 132 \\
\hline & Split & 88 & 1.58 & 1.55 & 139 & 0 & 6 & 2 & 102 \\
\hline & Sarajevo & 87 & 1.28 & 1.20 & 111 & 0 & 9 & 2 & 143 \\
\hline & Rijeka & 86 & 1.15 & 1.06 & 99 & 0 & 10 & 2 & 157 \\
\hline & Belgrade & 122 & 1.10 & 1.03 & 134 & 0 & 10 & 2 & 168 \\
\hline & Niš & 65 & 1.05 & 0.95 & 68 & 0 & 8 & 2 & 162 \\
\hline & Podgorica & 40 & 1.03 & 1.03 & 41 & 0 & 6 & 1 & 141 \\
\hline & Mostar & 35 & 0.66 & 0.66 & 23 & 0 & 3 & 1 & 133 \\
\hline & Skopje & 53 & 0.62 & 0.55 & 33 & 0 & 5 & 1 & 173 \\
\hline & Banja Luka & 63 & 0.41 & 0.34 & 26 & 0 & 5 & 1 & 245 \\
\hline & Priština & 66 & 0.38 & 0.25 & 25 & 0 & 9 & 1 & 323 \\
\hline
\end{tabular}


Figure 8. Arithmetic mean of h-index, by city

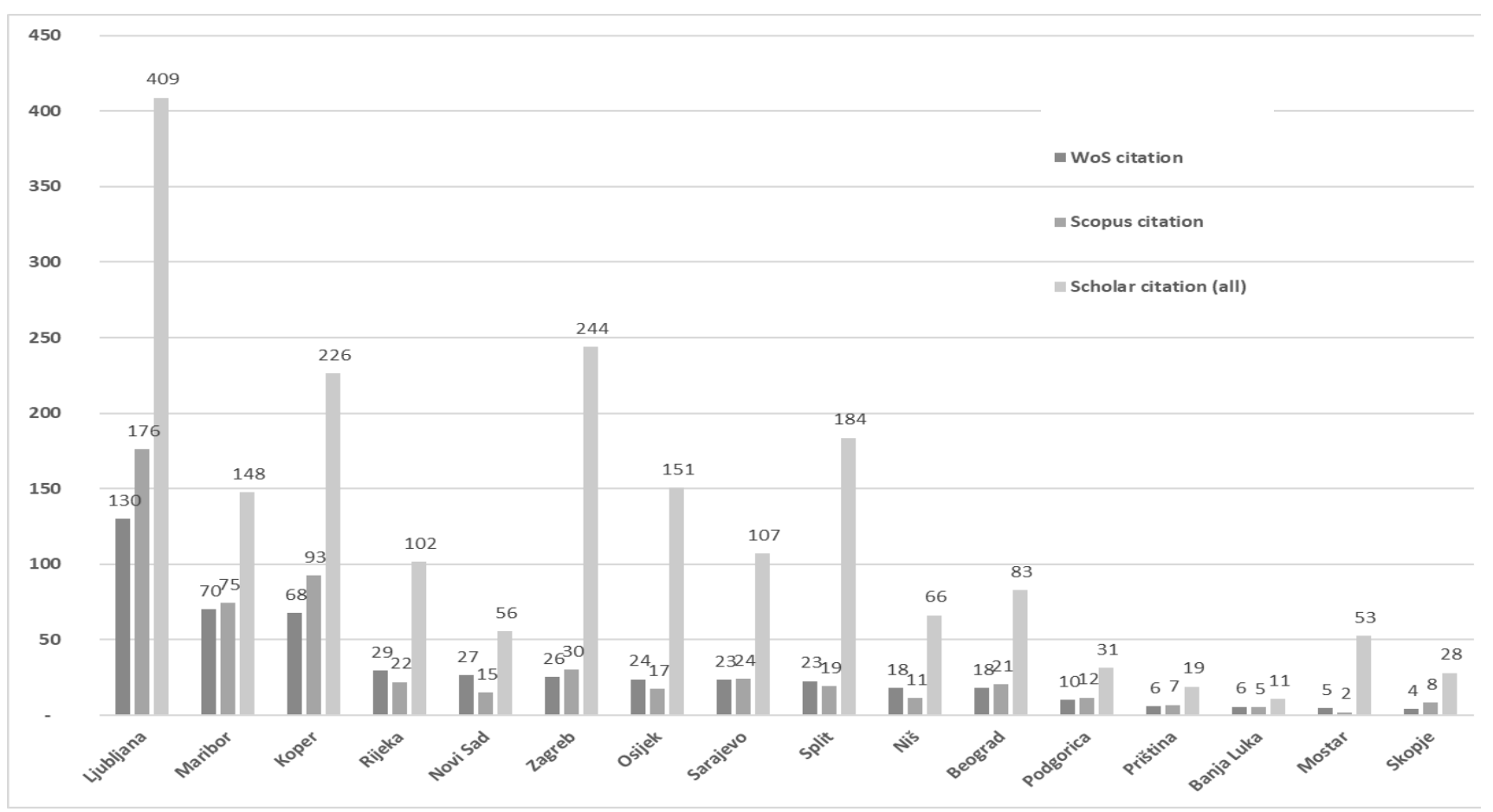

Source: Author's calculation

Are all the above differences significant, or are they random? Kolmogorov-Smirnov, Lilliefors and Shapiro-Wilk's W tests for normality were taken, and as they all exhibited $\mathrm{p}<.01$ the hypothesis that the respective distributions are normal was rejected. Therefore, Kruskal-Wallis non-parametric analyses of variance was performed, and all the variables (scientometrics) were found to be highly significant ( $\mathrm{p}<$ ,001). Thus, we can conclude that metrics are significantly different between countries and between cities.

The results imply that there are substantial inter- and intranational discrepancies regarding scientific impact and influence of higher education lecturers of economics in the CEE region. There are many possible explanations regarding the differences of economists' scientific impact between countries. We can conjecture that most of them are due to general economic inequalities. If within selected countries we compare total expenditure on R\&D (average from 2010 to 2018, by countries, unavailable for Kosovo) per inhabitant with average WoS citations per lecturer, we see a sharp trend line (Figure 8). Causality could here be disputed due to low number of data points, but there is an inherent logic connecting expenses on $R \& D$ and scientific impact of these investments.

Scientists almost everywhere could always complain that they are underfunded, but this is especially the case in emerging countries, as they were already constantly lagging behind and still are woefully lacking in resources. Even today many researchers from the observed countries do not have access to prime scientific resources - papers and data behind paywalls. Also, for decades talents went abroad; some of the best and brightest left in pursuit of better opportunities which certainly impoverished the remaining communities (Schierup
(1995), Straubhaar (2000), Horvat (2004)). These are some of the possible explanations of the divergence found within bibliometric data.

Figure 8. R\&D expenses per capita compared to average WoS citations

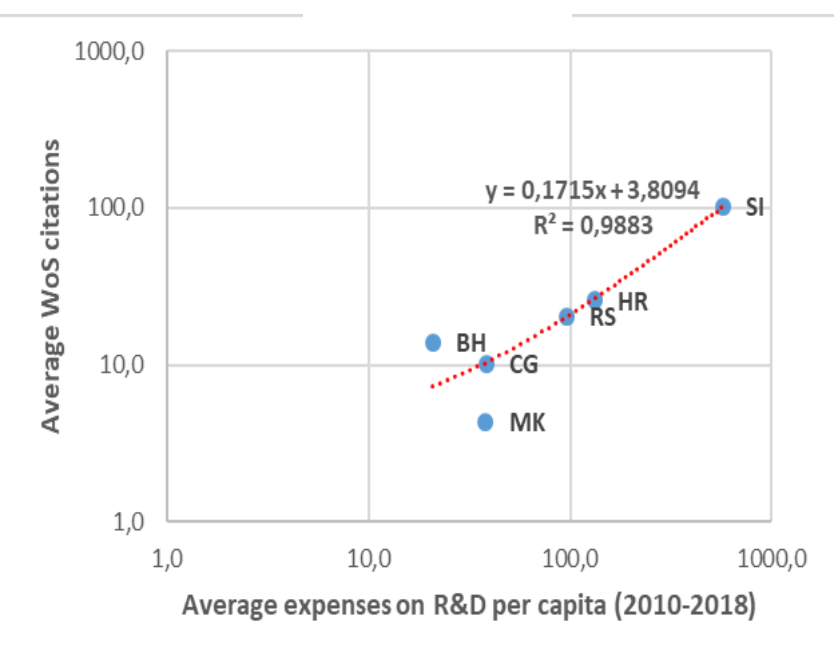

Source: UNESCO (2020) and Author's calculation

Furthermore, the obtained data can be valuable to:

- lecturers themselves in search for colleagues in their field,

- editors of journals when seeking reviewers,

- organizers of scientific conferences,

- journalists looking for expert opinions,

- policy makers when deciding on academic promotion requirements, 
- faculty management in scrutinizing inter-institutional development, mobility, scientific progress, project funding, cooperation and rewarding,

- industry servicing scientific community (e.g., in devising rankings, accreditations, etc.) and

- other stakeholders.

\section{Conclusion}

This paper contributes by obtaining and analysing a novel dataset on the scientometrics of CEE higher education lecturers of economics. Using web algorithms developed specially for this purpose, citations and h-indices were collected from Google Scholar, Web of Science, and Scopus for 1400 positions at the 16 largest faculties from seven countries. Colleagues from the neighbouring countries, from similar fields, now have a new tool for networking, as the data on the lecturers at public faculties is collected and available in the public domain.

The countries in the sample have very contrasting features; even though they share some of their history and background there has always been a significant economic gap (both in terms of science and the real economy) between them. These differences are evident in the scientific impact made by these locations. On average, nearly half of the lecturers do not have any profile at WoS, Scopus, or at Google Scholar, which renders them globally "invisible". This could be because they publish in their native languages, because they deal with locally specific issues, or because they are not committed to scientific publishing.

Besides as a ranking tool, the results are significant as they bear relevance for evaluating scientific progress, mobility, and cooperation, rewarding and promotion requirements, accreditations, funding projects and institutions, promotion of lecturers, and for other purposes.

Future researchers should expand the scope of the sample and include other neighbouring CEE countries. It would also be interesting to compare the amount of funds received by a faculty from the taxpayers with its scientific impact. In addition, qualitative impact measures could also be taken into account, which could enable detection of group identities as described by Vogel (2012). Furthermore, state-owned higher education institutions should be contrasted with privatelyowned ones. All things considered, we call for a deeper and wider exploration of gaps between higher education lecturers of economics in the region.

\section{Endnotes}

${ }^{1}$ One should be aware of the differences in terminology in higher education; in central and eastern European as well as in this paper "Faculty" is an institution similar to "College" in the USA, with synonyms such as "higher education institution" and "School".

${ }^{2}$ Link is temporarily hidden due to anonymization of authorship during the review process.

${ }^{3}$ The exception is the affiliation of the author (Osijek) which is not among the three largest in Croatia but was included in order to compare it to the selected sample.

${ }^{4}$ For an analysis of h-index within WoS, see Hu et al. (2020).

\section{References}

AAUP. (2015). American Association of University Professors: Policy Documents and Reports (11th ed.). Johns Hopkins University Press Books. Retrieved from https://jhupbooks.press.jhu.edu/title/policy-documents-and-reports

Blau, P. M. (1996). The Organization of Academic Work (2nd edition). Routledge. Retrieved from http://journals.sagepub.com/doi/10.1177/0270467696016001112

Boyer, E. L. (1997). Scholarship Reconsidered: Priorities of the Professoriate (1st edition). Jossey-Bass.

Candan, G. (2020). Efficiency and performance analysis of economics research using hesitant fuzzy AHP and OCRA methods. Scientometrics. https://doi.org/10.1007/s11192-020-03584-5

Google LLC. (2020, June 16). Google Scholar Metrics Help. https://scholar.google.hr/intl/en/scholar/metrics.html\#coverage

Hirsch, J. E. (2005). An index to quantify an individual's scientific research output. Proceedings of the National Academy of Sciences, 102(46), 16569-16572. Retrieved from https://doi.org/10.1073/pnas.0507655102

Horvat, V. (2004). Brain drain. Threat to successful transition in South East Europe. Southeast European Politics, 5(1), 76-93.

Hu, G., Wang, L., Ni, R., \& Liu, W. (2020). Which h-index? An exploration within the Web of Science. Scientometrics, 123(3), 1225-1233. https://doi.org/10.1007/s11192-020-03425-5

Jurajda, Š., Kozubek, S., Münich, D., \& Škoda, S. (2017). Scientific publication performance in post-communist countries: Still lagging far behind. Scientometrics, 112(1), 315-328. https://doi.org/10.1007/s11192-017-2389-8

Kocher, M. G., Luptacik, M., \& Sutter, M. (2006). Measuring productivity of research in economics: A cross-country study using DEA. Socio-Economic Planning Sciences, 40(4), 314-332. https://doi.org/10.1016/j.seps.2005.04.001

Schierup, C.-U. (1995). Former Yugoslavia: Long waves of international migration. In R. Cohen (Ed.), The Cambridge Survey of World Migration (1st ed., pp. 285-288). Cambridge University Press. https://doi.org/10.1017/CBO9780511598289

Scopus. (2020a). How Scopus Works. Scopus. Retrieved from https://www.elsevier.com/solutions/scopus/how-scopusworks/content

Scopus. (2020b, June 16). How can I use an h-graph? Retrieved from https://service.elsevier.com/app/answers/detail/a_id/11214/c/10546/supporthub/scopus/ 
Straubhaar, T. (2000). International mobility of the highly skilled: Brain gain, brain drain or brain exchange (Working Paper No. 88). HWWA Discussion Paper. Retrieved from https://www.econstor.eu/handle/10419/19463

UNESCO. (2020). Science, Technology and Innovation. UNESCO Institute for Statistics. Retrieved from http://data.uis.unesco.org/Index.aspx?DataSetCode=SCN_DS

Vogel, R. (2012). The Visible Colleges of Management and Organization Studies: A Bibliometric Analysis of Academic Journals. Organization Studies, 33(8), 1015-1043. https://doi.org/10.1177/0170840612448028

Waltman, L. (2016). A review of the literature on citation impact indicators. Journal of Informetrics, 10(2), $365-391$. https://doi.org/10.1016/j.joi.2016.02.007

Web of Science. (2020a). Web of Science Core Collection. Web of Science Core Collection. Retrieved from https://clarivate.com/webofsciencegroup/solutions/web-of-science-core-collection/

Web of Science. (2020b, June 16). Web of Science: H-index information. Retrieved from https://support.clarivate.com/ScientificandAcademicResearch/s/article/Web-of-Science-h-indexinformation?language $=$ en_US

Wolszczak-Derlacz, J., \& Parteka, A. (2011). Efficiency of European public higher education institutions: A two-stage multicountry approach. Scientometrics, 89(3), 887. https://doi.org/10.1007/s11192-011-0484-9

\section{Znanstveni vpliv predavateljev visokošolskega izobraževanja v Srednji in Vzhodni Evropi}

\section{Izvleček}

Namen te študije je pridobiti in analizirati podatke o visokošolskih predavateljih na 16 največjih ekonomskih fakultetah v državni lasti v sedmih državah Srednje in Vzhodne Evrope (Bosna in Hercegovina, Hrvaška, Kosovo, Črna gora, Severna Makedonija, Srbija in Slovenija), o njihovem znanstvenem vplivu in dosegu. Izvedena je bila analiza njihovih raziskovalnih področij in scientometrija (citati, h-indeksi), pri čemer je predstavljena skupna razvrstitev. Podatki so bili zbrani iz Google Scholar, Web of Science in Scopus z uporabo lastniških specializiranih spletnih pajkov ("botov"). Razlike med državami in med fakultetami so velike, institucije pa bi morale upoštevati dobre prakse iz Slovenije, saj so se fakultete iz te države uvrstile najvišje. Vpogledi so pomembni za ocenjevanje znanstvenega napredka, mobilnosti in sodelovanja, zahtev po nagrajevanju in napredovanju, akreditacije, financiranje projektov in ustanov ter napredovanje predavateljev v visokem šolstvu.

Ključne besede: Srednja in Vzhodna Evropa, ekonomisti, ekonomska fakulteta, scientometrija, h-indeks, citati 